\title{
Inequities in the emergence, manifestations and consequences of COVID19
}

\section{Las inequidades en la emergencia, las manifestaciones y las consecuencias del COVID19}

\author{
Fabian Mendez ${ }^{1}$ \\ fabian.mendez@correounivalle.edu.co \\ 1 Universidad del Valle, Facultad de Salud, Escuela de Salud Publica, Cali, Colombia.
}

\section{OPEN ACCESS}

Citation: Méndez F. Inequities in the emergence, manifestations and consequences of COVID19. Colomb Med (Cali). 2021;52(1): e104778

http://doi.org/10.25100/ cm.v52i1.4778

Keywords:

Pandemics; COVID-19; SARS-CoV-2; poverty; ecosystem; pesticides; food security; health education; drug industry; biodiversity; health services accessibility; pharmaceutical preparations.

Palabras clave:

Desigualdad; pandemia; SARSCOV2; inequidad; COVID 19; pobreza; ecosistema; plaguicidas; seguridad alimentaria; educación para la salud; industria farmacéutica; biodiversidad; accesibilidad a los servicios de salud; preparaciones farmacéuticas.

Copyright: @ 2021 Universidad del Valle.

\section{(c) (7) ()}

Conflicts of interest:

none declared

\section{Abstract}

The Inequality Virus is the name given to SARS-COV2 by an OXFAM publication, highlighting that during the pandemic, the ten richest men on the planet have earned 540 billion dollars, a figure that would serve to finance a universal vaccine for COVID19. This fact is an exemplary demonstration of the inequities of the pandemic, analyzed below in three different dimensions: 1) The origins of the pandemic, in the context of inequitable socio-ecological systems where the relationship amongst humans and between humans and nature has been broken; 2) Its manifestations, in conditions of social inequity, with its patterns of occurrence and a painful trace of disease and death; and 3) The consequences, in a vicious circle with the complex systems that gave rise to it, causing a profound situation of inequity, in other words, the pandemic as a source of more unjust differences.

\section{Resumen}

El virus de la desigualdad, llama una publicación de OXFAM al SARS-COV2, al resaltar que durante la pandemia los 10 hombres más ricos del planeta han ganado 540.000 millones de dólares, una cifra que serviría para financiar una vacuna universal para el COVID19. Este hecho es una ejemplar demostración de las inequidades de la pandemia, analizadas a continuación en tres dimensiones diferentes: 1) Los orígenes de la pandemia, en medio de sistemas socio-ecológicos inequitativos donde se ha roto la relación entre los seres humanos y de estos con la naturaleza; 2) Sus manifestaciones, en condiciones de inequidad social, con sus patrones de ocurrencia y un doloroso rastro de enfermedad y muerte; y 3) Las consecuencias, en un círculo vicioso con los complejos sistemas que dieron su origen, causando una profunda situación de inequidad, en otras palabras, la pandemia como fuente de más diferencias injustas. 
Corresponding author:

Fabián Mendez. Universidad del Valle, Facultad de Salud, Escuela de Salud Publica, Cali, Colombia.

e-mail: fabian.mendez@

correounivalle.edu.co
The Inequality Virus is the name given to SARS-COV2 by an OXFAM publication, highlighting that during the pandemic, the ten richest men on the planet have earned 540 billion dollars, a figure that would serve to finance a universal vaccine for COVID19 ${ }^{1}$. This fact is an exemplary demonstration of the inequities of the pandemic, analyzed below in three different dimensions: 1) The origins of the pandemic, in the context of inequitable socioecological systems where the relationship amongst humans and between humans and nature has been broken; 2) Its manifestations, in conditions of social inequity, with its patterns of occurrence and a painful trace of disease and death; and 3) The consequences, in a vicious circle with the complex systems that gave rise to it, causing a profound situation of inequity, in other words, the pandemic as a source of more unjust differences.

In first place, there have been so many warning signs both from modern scientific knowledge, as well as the ancient voices of many native peoples, pointing to the ontological rupture of our society with nature as the root of many of our social ills and the affectation of individual and collective health. This rupture is present in our modern ways of life and is manifested in the ways we see, feel, understand and act in our relationships with other living beings on this planet. It is in the midst of this rupture full of inequity and socio-environmental violence that the current pandemic appeared. Under the precepts of objectivity, science, competitiveness, individuality, and autonomous achievement of success, we have launched ourselves as a society into a boundless race. A race towards development that brings the promise of technologies and innovation that will surely lead us to prosperity. Under this premise, it seems that it is possible to go beyond the physical limits of this planet. We will be able, for example, to produce more industrialized agriculture at the expense of biodiversity and the food security and sovereignty of the most vulnerable. This is why we have pushed the limits of our delusional dreams with mass production projects that ignore natural cycles; we have expanded mining extractivism and extended the agricultural frontier, bursting into biodiversity-rich territories to develop industrial production models based on fossil fuels, pesticides and transgenic seeds. It is precisely in the territories of greatest biodiversity that the previous pandemics have arisen and those to come will arise ${ }^{2}$. Behind the anecdote of Wuhan lies a history of global violence, predation, and inequitable growth at the expense of the most vulnerable peoples, wild animals and ecosystems razed to make way for constant development. It was there that SARS-COV2 emerged and in similar contexts, the Nipah, Ebola, AIDS and other viruses emerged.

Secondly, SARS-COV2 is what it is today because it was able to be transmitted under conditions of social and ecological inequity. The global novelty of this pandemic is that disease and death reached Europe and North America in numbers not seen since the last influenza epidemic a century ago. However, although COVID19 has become globally distributed and creates a situation in which it seems that "everyone on the planet is in this", in truth, the inequity cruelly demonstrates that the pandemic has not been and will not be the same for everyone. It is evident that the pandemic does not manifest itself in the same way in the North as in the global South. At different scales and in different geographical and political contexts, COVID19 manifests itself unequally amidst the complex intersectionalities of gender, race-ethnicity and socioeconomic position. To give a few examples, in Europe, it is the countries that have most privatized their health systems (i.e., Italy and Spain) that have suffered the greatest burden of morbidity and mortality ${ }^{3}$; it is rural and urban communities crowded in squalor circles without access to water that are the most vulnerable ${ }^{4}$; within Israel, the country that was the fastest to establish an immunization program, Palestinians have no access to vaccination ${ }^{5}$.

And as some have clearly stated: we do not die from COVID but from pre-existing diseases, diseases that are the result of inequalities, since the social configuration of risk explains how conditions of vulnerability are embodied in the bodies of women, racialized peoples and the poorest: obesity, hypertension and uncontrolled diabetes, to name the best known. To which it should be added that in the midst of this situation of crisis and the fracture of the health system, access to treatment of chronic conditions has been further limited and synergies 


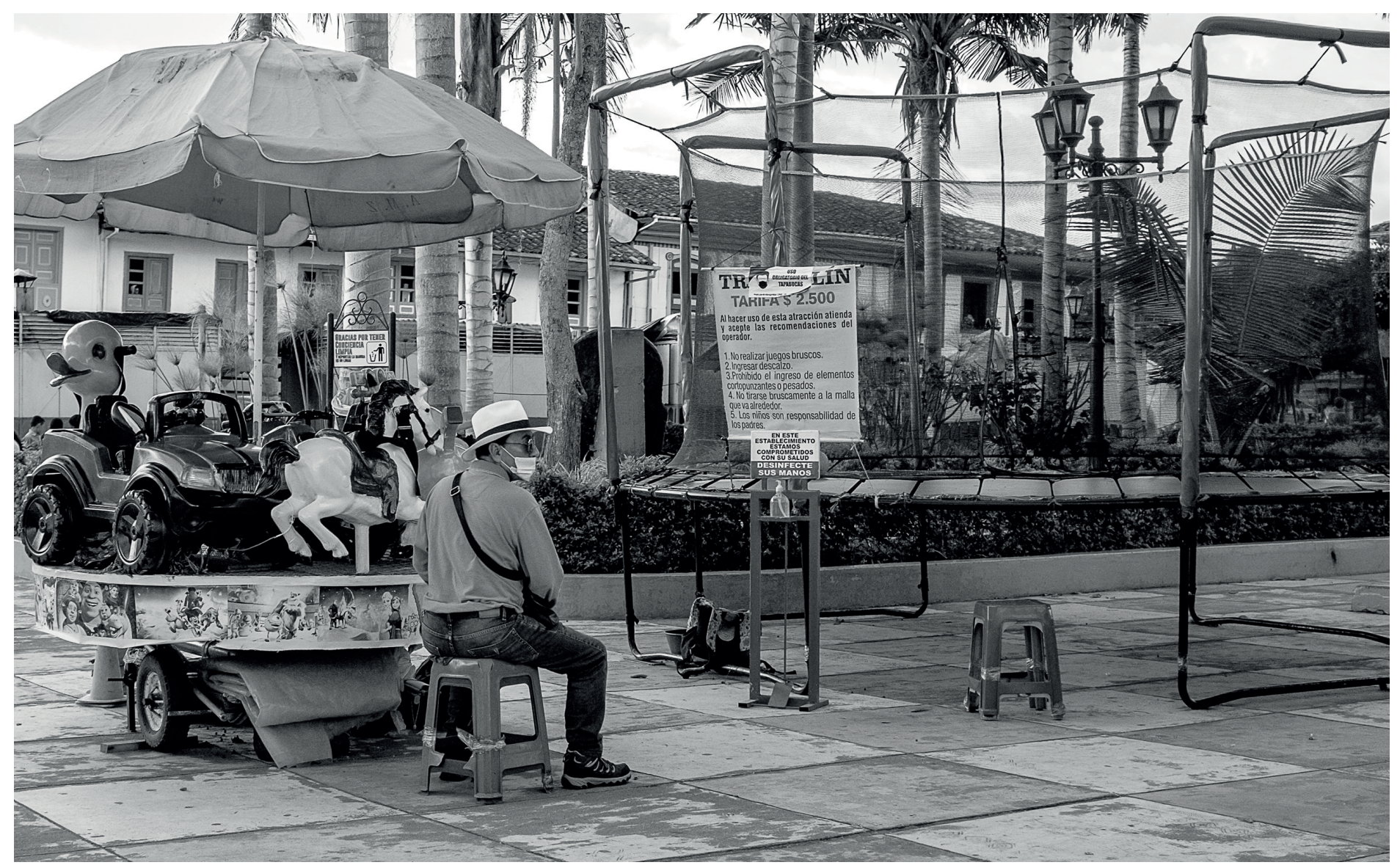

Figure 1. Inequity cruelly demonstrates that the pandemic has not been and will not be the same for everyone. Unemployment in the midst of confinement impacted the most vulnerable the hardest. Photo taken in Salento (Quindio, Colombia) (F. Méndez)

with violence, mental illness and other infectious and preventable diseases (syndemic) have manifested. For example, according to the Observatorio Feminicidios Colombia, during 2020, 630 of these crimes were registered in Colombia, representing almost a 10\% increase compared to the previous year ${ }^{6}$.

Despite the apparent "abnormality", it should be recognized that we are NOT facing exceptional conditions. Paradoxically, this singular situation is the manifestation of an inequality that has become normal. We are all asked to distance ourselves socially when we live at a distance from each other. There are great social distances between the lives of women and men; between black, indigenous and other ethnic minorities and white populations; between rural dwellers and those living in cities; between lower-income people living in vulnerable territories and higher-income people living in healthy environments.

Even in the context of contemporary societies oriented by the market and competitiveness, it would seem surprising that under the humanitarian crisis of this pandemic there is a worsening of conflicts between world powers, border closures to travelers from countries with new viral variants and the struggle for access to vaccines between states with nationalist rhetoric. But in reality, after the Second World War, we have not stopped escalating arms production, hordes of desperate migrants clash with border walls, and nationalist discourses occupy the political agenda of many parties in power. The unequal negotiation for vaccines between entire nations and pharmaceutical companies seems surprising, when the rules of the market and the inequitable conditions of drug patents are what have given these transnationals the economic power they now wield in the world (dis)order; we are surprised that today many 
do not have access to timely diagnosis and treatment for COVID19, when poor access to services is the rule in a system where economic interests prevail over health. And that is why the much-talked-about desire to return to "normality" seems as innocuous as it is unnecessary, because it seems that yes, we will return to normality, without ever having abandoned it.

Finally, the impact of the pandemic on living conditions is not only evident at the economic level, with an increase in unemployment, economic decline and the affectation of the world development model, but is also expressed with a greater deepening of inequality conditions (Figure 1). According to the Economic Commission for Latin America and the Caribbean (ECLAC) ${ }^{7}$ it is estimated that the total number of people living in poverty increased from 185.5 million in 2019 to 230.9 million in 2020 , representing $37.3 \%$ of the population. The economic debt in the international financial markets of middle and low-income nations is already beginning to translate into further cuts in health, education and, in general, a weakening of redistributive policies. This is not a change in the global trends that had been leading to the prevalence of a single world vision with a preponderance of economic interest; it is an acceleration that will lead to more of the same, to small states opening up space for the private sector, to entrepreneurship, to universities turning gears in the development machine. In contrast, it is not recognized that public funding from the world's major economic powers to the private sector was an essential ingredient for the development of vaccines in record time, although the pharmaceutical industry will benefit greatly ${ }^{8}$.

As De Sousa Santos has mentioned, there is a cruel pedagogy in this virus ${ }^{9}$. The problem is whether we will learn anything new from it. In a society overrun with information we need to make greater and deeper historical and political connections to produce knowledge. We need to combine basic science with ecological economics and the political philosophy of pandemics, in an ethical dialogue with other ways of seeing the world, particularly those who historically have not been able to be heard. It will do us no good in this cruel apprenticeship to recognize the molecular variants of SARS-COV 2 if we do not build a more just society and if we do not rebuild a healthy peace with nature. This civilizational change may seem utopian, but as academics, we have an obligation to see it through.

\section{References}

1. Berkhout E, Galasso N, Lawson M, Rivero Morales PA, Taneja A, Vasquez Pimentel DA. El virus de la desigualdad: cómo recomponer un mundo devastado por el coronavirus a través de una economía equitativa, justa y sostenible. Oxfam; 2021 p. 85.

2. Morse SS, Mazet JA, Woolhouse M, Parrish CR, Carroll D, Karesh WB, et al. Prediction and prevention of the next pandemic zoonosis. Lancet. 2012; 380(9857):1956-65.

3. Armocida B, Formenti B, Ussai S, Palestra F, Missoni E. The Italian health system and the COVID-19 challenge. Lancet Public Health. 2020; 5(5): e253.

4. Jiwani SS, Antiporta DA. Inequalities in access to water and soap matter for the COVID-19 response in sub-Saharan Africa. Int J Equity Health. 2020; 19(1): 82.Jiwani SS, Antiporta DA. Inequalities in access to water and soap matter for the COVID-19 response in sub-Saharan Africa. Int J Equity Health. 2020;19(1):8282. [PubMed] [Google Scholar]

5. Martin S, Arawi T. Ensure Palestinians have access to COVID-19 vaccines. Lancet. 2021; 397(10276): 791-2.

6. Red Feminista Antimilitarista. Feminicidios en Colombia. 2020. Cited: 2021 Mar 1. Available from: http://www. observatoriofeminicidioscolombia.org/attachments/article/451/Feminicidios\%20en\%20colombia\%202020.pdf

7. Filguera F, Galindo LM, Giambruno C, Blofield M. América Latina ante la crisis del COVID-19: vulnerabilidad socioeconómica y respuesta social. Santiago: CEPAL; 2020.

8. Allen A. For billion-dollar covid vaccines, basic government-funded science laid the groundwork. Scientific American; 2020. Cited 2021 Mar 1. Available from: https://www.scientificamerican.com/article/for-billion-dollarcovid-vaccines-basic-government-funded-science-laid-the-groundwork/.

9. de Sousa SB. La cruel pedagogía del virus. Series: Biblioteca Masa crítica. CLACSO; 2020. Doi: 10.2307/j. ctv1gm01nn. Available from: https://www.jstor.org/stable/10.2307/j.ctv1gm01nn 